\title{
MaRIS - Migration and Refugee Information Studies Research Project
}

\author{
Eeva-Liisa Eskola \\ Åbo Akademi University, Information Studies \\ eeskola@abo.fi \\ http: //orcid.org/0000-0002-3748-4497
}

Riitta Hämäläinen

Helsinki City Library

riitta.hamalainen@hel.fi

\begin{abstract}
Anne Ojanperä
Helsinki City Library

anne.ojanpera@hel.fi
\end{abstract}

\section{Hilda Ruokolainen}

Åbo Akademi University, Information Studies

hilda.ruokolainen@abo.fi

http: //orcid.org/0000-0003-2521-4390

\begin{abstract}
According to the statistics of the United Nations High Commissioner for Refugees (UNHCR 2017) from 2015 there were 65.3 million forcibly displaced people around the world. Global migration can be expected to be a large question in the world also in the future, for example, the recent refugee and asylum seekers crises in Europe brought with it a number of challenges on many levels. One of the major challenges is connected to communication and information. The goal of the MaRIS project is to strengthen the research in the area of refugee information practices, needs, seeking and use, as well as to promote dialogue and collaboration between the researchers and the practitioners interested in the topic.
\end{abstract}

Asiasanat: refugees; asylum seekers; projects; library services; service needs; service design; workshops Artikkeli on lisensoitu Creative Commons Nimeä-EiKaupallinen-JaaSamoin 4.o Kansainvälinen -lisenssillä 
Refugees have been a subject of study in different disciplines, investigating, among others, economic, social, political and legal issues, but there is relatively little research internationally (Caidi, Allard, \& Quirke, 2010) and specifically in Finland focusing on their information behaviour or practices (Aarnitaival, 2012, p. 12). Therefore, more empirical research is needed to identify the characteristics of information practices, needs and uses of refugees and immigrants not only to contribute to theory building, but also to produce knowledge which helps the processes involved in asylum seeking and social inclusion.

During the last years researchers at schools of library and information science in the Nordic countries have conducted research on the topic in question (e.g. Audunson, Essmat, \& Aabø, 2011; Hultgren, 2013; Lloyd, 2016; Vårheim, 2014). In 2016 the MaRis project was initiated in the unit of Information Studies at Åbo Akademi University ( $\AA \mathrm{AU})$. The project is connected to minority research, which is identified as one of the four profile areas of research at ÅAU. The Minority Research profile is a strategic and cross-boundary research area "which taps into the new situation where cultural, political and religious differences together with issues related to in-group and out-group positions pose major challenges to societal cohesion, peace-building and human well-being on a global scale" (Åbo Akademi University, 2017). Professor Karen Fisher from the Information School at University of Washington, who has experience with research on immigrants' and refugees' information behaviour (Fisher, Bishop, Fawcett, \& Magassa, 2014; Fisher, Durrance, \& Hinton, 2004; Fisher, Yefimova, \& Yafi, 2016), is recruited part time to support and further strengthen the profile.

The main activities of MaRIS consist so far of organizing seminars and workshops as well as involvement in the project of Helsinki City Library which explored the library service needs of asylum seekers in 2016. The overview of the survey is presented later in this article. Another co-operator of MaRIS is The Swedish School of Library and Information Science (SSLIS) at the University of Borås which was a co-organizer of the Nordic seminar and workshop held at $\AA A$ U in spring 2017.

Additional activities implemented in the framework of MaRIS include:

- The workshop on Information Behaviour and Information Practices among Minority and Special Groups at the Information studies symposium 2016 in Tampere, Finland, which attracted submissions from researchers exploring information behaviour of various special/minority groups, 
- \#WithRefugees - Workshop on Field and Design Methods for Supporting Refugees through Library Services and Other Social and Policy Innovations held in the IConference in Wuhan, China in March 2017,

- the presentation of the findings from the fieldwork at Za'atari Refugee Camp in Jordan on Refugees' Everyday Information Needs, Seeking, and Use of Technology, which will take place at the satellite meeting of IFLA World Library and Information Congress in August 2017.

\section{Bringing together the key actors and designing services - Experiences from two workshops}

To link scientific research and practical implementation in the area of refugee information practices, seeking and use two seminars with workshops has been held at ÅAU. The first MaRIS workshop on national level "Libraries, Refugees and Integration" was held in May 2016, and the second one, on the Nordic level, on the theme "Integration in Cooperation: Developing Information Services for Refugees in Collaboration with Key Actors" in May 2017.

The workshops focused on research being conducted in the area but also explored tools and methods to map information and library service needs among refugees and immigrants. The workshops were attended by library staff, researchers, teachers and students in library and information science, representatives of officials and non-governmental organizations and immigrants, as well as persons with refugee background. One of the methods explored both theoretically and in practice was the design thinking method.

Design thinking process is different from analytical and linear problem solving process, and it suits better for uncertain and complex situations where people are the key evaluators of the situation and solutions (Glen, Suciu, Baughn, \& Anson, 2015). Design thinking comprises five elements: empathize (learn about your audience/user), define (create a point of view based on user needs and insights), ideate (brainstorm), prototype (build representations), and test (show your prototype with your original user for feedback). Design thinking has also been developed as a Toolkit for Libraries (IDEO, 2015).

In the design thinking workshops the attendees designed in groups information services for refugees with special needs and found solutions how to cooperate better with other actors when developing those services. As a result of the process the groups came up with creative ideas and practical solutions such as an app for immigrants seeking work. The app would give necessary preliminary information about job seeking opportunities and connect the person to a personal contact, 'A cultural 
guide to working life' to get further information. The overall outcomes of the workshops were that they were successful; the speakers gave good insight into the topics both theoretically and by presenting best practices. The learning experience during the design sessions gave the participants concrete ideas on how to develop information services and collaborate in knowledge sharing as well as understanding of the methodology.

\section{Library service needs of refugees - Overview of the survey conducted by the Helsinki City Library}

Many actors in society are involved in the integration of newcomers and try to bring some support to the difficulties that refugees and other immigrants face when arriving in a new country. Libraries throughout the world have taken an active role in the integration process and developed their services including for example, acquiring information sources in different languages, organizing interaction programs and services to different groups of refugees and immigrants (e.g. Dali, 2013; Johnston, 2016; Lovio, 2010). In Finland one of the recent library initiatives is the survey of library service needs of the asylum seekers conducted by the Helsinki City Library - the Central Library for Public Libraries in Finland - in 2016 (Baghbani, Hewidy, Hämäläinen, Larva, \& Ojanperä, 2016).

The survey was made with financial support from the Ministry of Education and Culture. Altogether 113 refugees were interviewed in the metropolitan area, Tur$\mathrm{ku}$, Joutseno and Kauhava. Those interviewed spoke Arabic, Persian (Dari), Pashto, Kurdish or Somali. The average age of adult interviewees was 29 and most had either comprehensive school or second or third degree. More than half, almost $60 \%$ of those interviewed had used library services while living in Finland. It can be deduced from the survey that the educational background and language skills had an effect on how library services were used, for example how the interviewees learned about library and library services and how to use them, and on reading habits and voluntary language studies.

As a control group, 28 people with an immigrant or multicultural background were interviewed in the metropolitan area. Both groups, refugees as well as the members of control group, wished for multilingual information outside of the library. They were willing to participate and to have a say in the way services are being developed and implemented.

Refugees come from countries that do not have the same kind of open to all library system that Finland has. Many of them do not necessarily know the service principles of public library, for example, that anyone can come to a library just to spend time or that in principle library services are free. Even if the interviewees 
had used libraries in their own countries, they did not know that in addition to books, the Finnish libraries have many other materials and services available. It was requested that the library would offer support especially for language learning and getting to know the Finnish society and culture.

Two separate questionnaires were sent to libraries. Those, mostly small and medium-size libraries, which had little or no experience with refugee/immigrant customers, and bigger cities which had more and longtime experience. The libraries were asked which services and activities they have for newcomers and what kind of help and information they need in developing the services. Additionally, the libraries were asked about cooperation with other actors. Also representatives of different organizations working with refugees or asylum seekers in the metropolitan area were interviewed in order to explore their knowledge of library services for newcomers and whether they had utilized the services in the context of their work.

The inquiries and interviews showed that local cooperation in municipalities and information sharing is of vital import. Library services are not necessarily well known among other agencies and organizations which are, or would be, important partners. Cooperation between various agencies and organizations is necessary background as support also for libraries. Libraries need to be active also in this and in spreading information on available services. Newcomers' participation in developing these services must not be overlooked.

\section{Strengthening research opportunities and promoting dialogue by networking}

The activities undertaken by the MaRIS project so far have already shown to be valuable from knowledge sharing and service design point of views. Research in the area is needed and there is growing interest in the topic, at $\AA A U$ one doctoral student has recently initiated a research project on information behavior among Iraqi asylum seekers.

In the future the MaRIS project seeks to strengthen the research opportunities by establishing joint research initiatives together with other information schools and further promoting dialogue and collaboration between the researchers and the practitioners interested in the topic of refugee information practices, needs, seeking and use. For the networking and information sharing purposes a Facebook group on the subject was established in 2016. If you do research that relates to MaRIS and you want to join the group, please contact Gunilla Widén at ÅAU (gwiden@abo.fi) or Annemaree Lloyd at Borås University (annemaree.lloyd@hb.se). 


\section{References}

Aarnitaival, S. (2012). Maahanmuuttajanaiset työelämätietoa etsimässä. Tutkimus kotoutumisen tietokäytännöistä (PhD thesis). University of Tampere; Tampere University Press. http://urn. fi/urn: isbn: 978-951-44-8800-9

Audunson, R., Essmat, S., \& Aabø, S. (2011). Public libraries: A meeting place for immigrant women? Library \& Information Science Research, 33(3), 220-227. https : //oadoi .org/10.1016/j.lisr. 2011. 01.003

Åbo Akademi University. (2017). Minority Research at Åbo Akademi University. http://www. abo.fi/ forskning/en/minorityresearch

Baghbani, K., Hewidy, N., Hämäläinen, R., Larva, T., \& Ojanperä, A. (2016). Selvitys turvapaikanhakijoiden palvelutarpeista. Lähtökohtia kirjastopalvelujen kehittämiselle. (p. 60). Helsinki: Helsingin kaupunginkirjasto - Yleisten kirjastojen keskuskirjasto. http://bit.1y/2s5HuUm

Caidi, N., Allard, D., \& Quirke, L. (2010). Information practices of immigrants. Annual Review of Information Science and Technology, 44(1), 491-531. https://oadoi .org/10.1002/aris. 2010.1440440118

Dali, K. (2013). ?Ask me what I read?: readers' advisory and immigrant adaptation. New Library World, 114(11/12), 507-526. https://oadoi.org/10.1108/NLW-06-2013-0054

Fisher, K. E., Bishop, A. P., Fawcett, P., \& Magassa, L. (2014). InfoMe: A Field-Design Methodology for Research on Ethnic Minority Youth as Information Mediaries. In D. Bilal \& J. Beheshti (Eds.), New directions in children's and adolescents' information behavior research (pp. 135-156). Emerald Publishing. https://oadoi.org/10.1108/S1876-056220140000010053

Fisher, K. E., Durrance, J. C., \& Hinton, M. B. (2004). Information grounds and the use of need-based services by immigrants in Queens, New York: A context-based, outcome evaluation approach. Journal of the American Society for Information Science and Technology, 55(8), 754-766. https: //oadoi.org/10.1002/asi.20019

Fisher, K. E., Yefimova, K., \& Yafi, E. (2016). Future's Butterflies. In Proceedings of the the 15th international conference on interaction design and children - idc '16 (pp. 25-36). New York: ACM Press. https://oadoi.org/10.1145/2930674.2930701

Glen, R., Suciu, C., Baughn, C. C., \& Anson, R. (2015). Teaching design thinking in business schools. The International Journal of Management Education, 13(2), 182-192. https ://oadoi .org/10.1016/ j.ijme. 2015.05.001

Hultgren, F. (2013). The stranger's tale: information seeking as an outsider activity. Journal of Documentation, 69(2), 275-294. https://oadoi.org/10.1108/00220411311300075

IDEO. (2015). Design Thinking for Libraries. A Toolkit for Patron-Centered Design. http://bit.ly/ $1 \times$ MixjP

Johnston, J. (2016). Conversation-based programming and newcomer integration: A case study of the Språkhörnan program at Malmö City Library. Library \& Information Science Research, $38(1)$, 10-17. https://oadoi.org/10.1016/j.lisr.2016.02.001

Lloyd, A. (2016). Reflection on: "On Becoming Citizens: Examining Social Inclusion from an Information Perspective". Australian Academic \& Research Libraries, 47(4), 316-319. https://oadoi. org/10.1080/00048623.2016.1256805

Lovio, I. (2010). Monikulttuurisuuden kehittäminen kirjaston palveluissa - PDF. Kirjastoinnovaatiothanke. http://docplayer.fi/1494548-Monikulttuurisuuden-kehittaminen-kirjaston-palveluissa. html

UNHCR. (2017). Figures at a Glance. http://www.unhcr.org/figures-at-a-glance.html

Varrheim, A. (2014). Trust and the role of the public library in the integration of refugees: The case of a Northern Norwegian city. Journal of Librarianship and Information Science, 46(1), 62-69. https://oadoi.org/10.1177/0961000614523636 